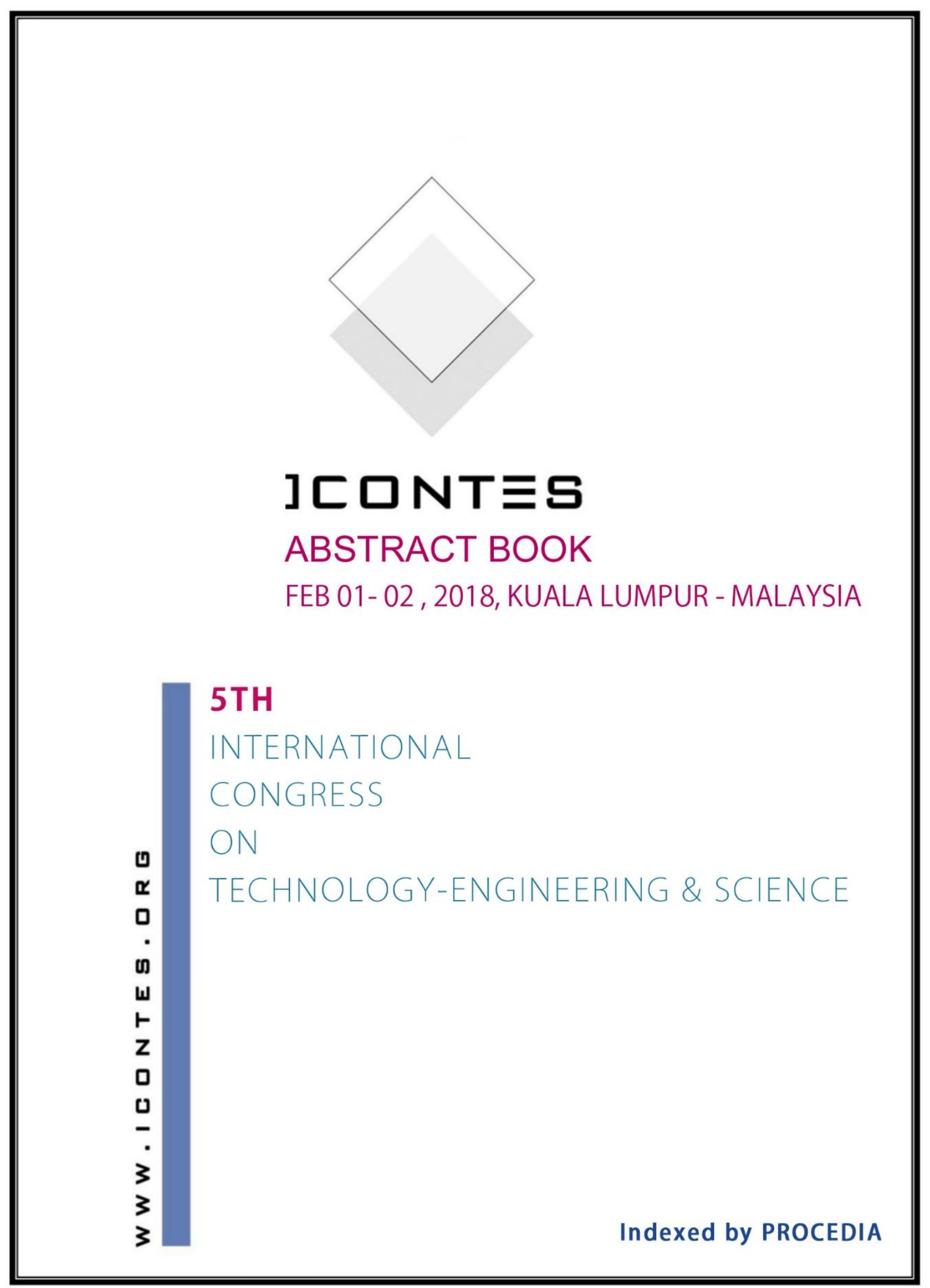




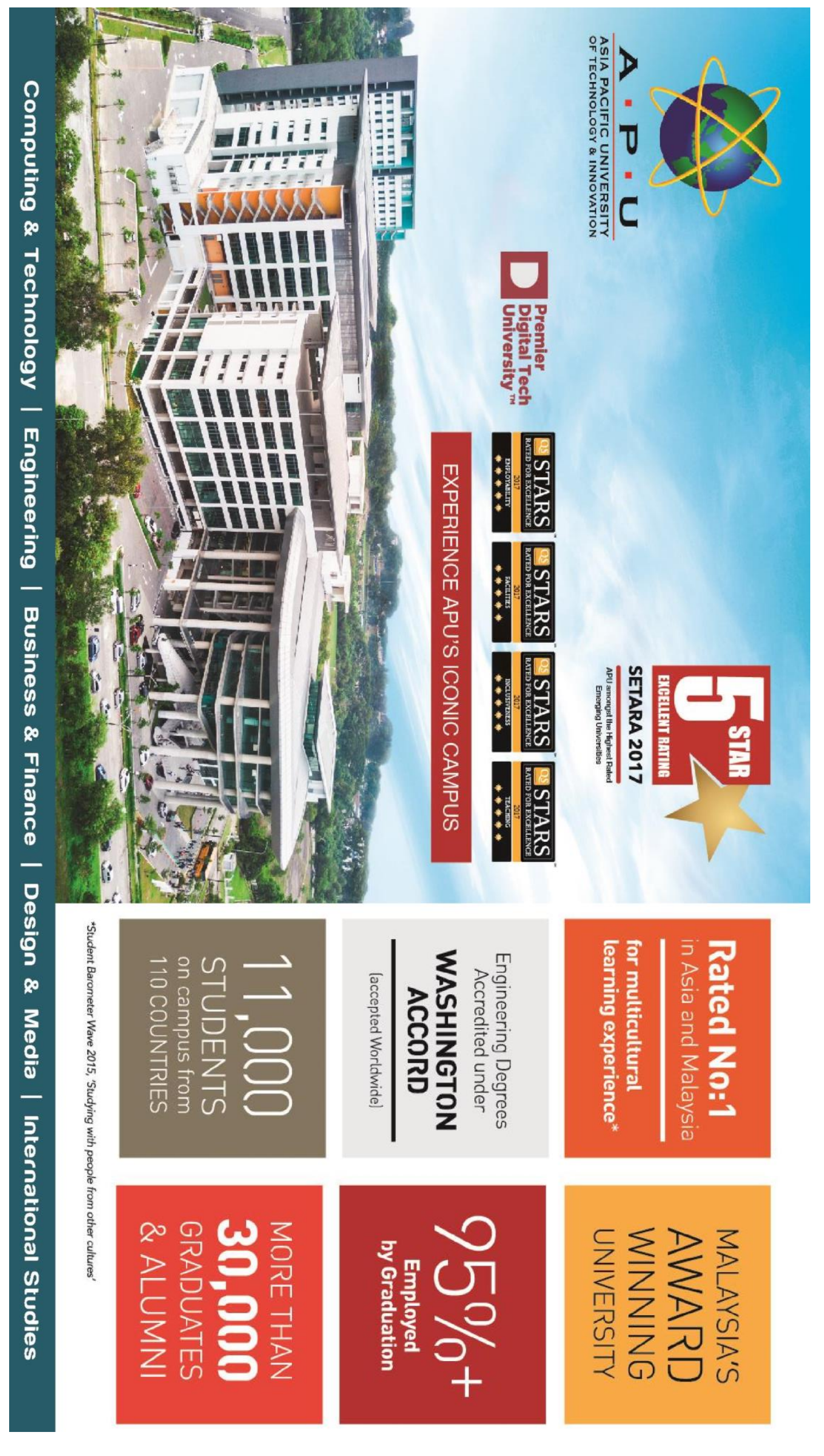


JСロNTES

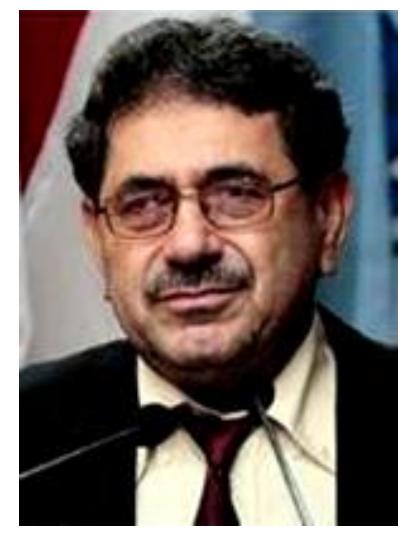

PROF. GHASEM D. NAJAFPOUR

Presentation Title:

\section{Enhanced Energy Recovery and Wastewater Treatment Efficiency in Microbial Desalination Cell}

\section{Brief Resume:}

Professor Ghasem D. Najafpour is a distinguished professor in Chemical Engineering and Chairman of Biotechnology Research Center, Babol Noshirvani University of Technology, Iran. He is an educated scholar from University of Arkansas, USA with strong background in biological processes. He is deeply involved in research and teaching in biochemical engineering subjects and he has conducted many practical researches in enzyme technology, fermentation processes, biodiesel, biofuel, biosurfactant, wastewater treatment and biochemical engineering.

He is a Chemical Engineer and Biotechnologist, B.Sc., Medical Technology University of Isfahan, Iran (1972), M.Sc., Chemical Engineering University of Oklahoma, USA (1977) and Ph.D., Chemical Engineering University of Arkansas, USA (1983). He served as assistant professor at University of Mazandran, Iran (1983-1989). Visiting Professor at University of Waterloo Canada and University of Arkansas, USA (1990-1991). He also spent his sabbatical leave at University of Arkansas, USA (1992-1993). There, he has expanded his scientific research activities on single cell protein (SCP), Microbial fuel cells, renewable energy and synthetic fuels. He served as associate professor at University of Mazandaran, Iran, (1994-1998) and Universiti of Sains Malaysia, Malaysia (1998 - 2005). Since 2005, he was qualified and appointed as professor in Faculty of Chemical Engineering at Babol Noshirvani University of Technology, Iran.

Since 2008, he is serving as Editor in Chief of International Journal of Engineering, World Applied Sciences Journal, and Middle East Journal of Scientific Research. He is also Editor in Chief of Iranica Journal of Energy and Environment since 2006. In addition, he is Editor of Journal of Environmental Chemistry and Ecotoxicology, Academic Journals, since 2007. He is an active member of many international institutes, editor and reviewers of number of international journals and many scientific societies. Often he is invited to many international conferences as keynote speakers. 
JСロNTES

In past decades, he has supervised more than 165 master and $38 \mathrm{Ph} . \mathrm{D}$. students. He has published more than 450 papers in international journals and has written 10 books in the field of Chemical Engineering and Biotechnology. In year 2006, he has published his $1^{\text {st }}$ edition of his book with Elsevier entitled "Biochemical Engineering \& Biotechnology". The 2nd edition of "Biochemical Engineering \& Biotechnology" with 20 chapters is published by Elsevier on Feb. 2015.

A few times, he has been awarded and appointed by the Ministry of High Education of Iran as the best and top researcher in Iranian Universities. He won number of awards for research achievements and winner of gold medal for the Invention/Innovation sponsored by Ministry of Science, Technology Malaysia, 2004. His researches for formulation of transparent soap and natural biodegradable liquid detergent from palm oil's fatty acids, was patented with SIRIM Berhad, Malaysia (2003). Currently, he is supervising number of $\mathrm{PhD}$ scholars and conducting top research projects on microbial fuel cells, biodiesel biohydrogen, biodiesel, biofuel from algae, bioethanol from agro-wastes, enzyme technology, renewable energy, heterogeneous catalytic processes, wastewater treatment and biological treatment processes. 
JСロNTES

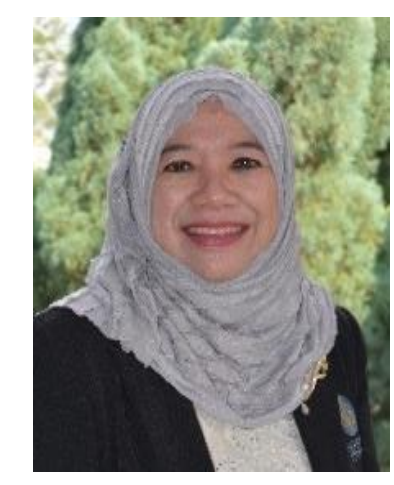

PROF. DR. NORANI MUTI MOHAMED

Presentation Title:

\section{Designing Nanomaterials to Maximize Performance}

\section{Brief Resume:}

Norani Muti is a professor at the Department of Fundamental \& Applied Sciences at Universiti Teknologi PETRONAS (UTP). Currently she is holding the position as a Director for UTP Centre of Innovative Nanostructures \& Nanodevices (COINN). She obtained her BSc, MSc and PhD in Physics from University of Essex, UK. She specializes in the area of Thin Film Technology, Semiconductor Technology and Nanotechnology. She established "Centre of Innovative Nanostructures and Nanodevices (COINN)" at UTP with the objective of establishing a library of nanomaterials and synthesis techniques for accelerated production of innovative and beneficial commercialized products. In 2011, COINN had been recognized as NanoMalaysia Centre of Excellence based on its continuous effort on R\&D on nanotechnology, focusing on alternative and renewable energy. Research works undertaken are very much focused on cutting-edge research areas ranging from novel materials with innovative nanostructures to novel nanodevices. She has published over 200 research papers with some of her achievements been awarded medals at various local and international exhibitions. About RM25 million in research funding has been secured with accomplishment of more than 10 research grants as principle investigator. She is also actively involved in International Organization of Standardization in Nanotechnologies (ISO/TC229) as the technical expert and as chairperson of working group 2 (measurement and characterization) in Malaysia. At international level, she is a Programme Management Board member of Lloyd's Register Foundation International Consortium of Nanotechnologies (LRF-ICON) which is based in Southampton, UK. Nationally, she is the fellow of the Academy of Sciences Malaysia (ASM) and the project leader in NanoMalaysia Institute for Innovative Technology (NanoMITe) Global Research Consortium. 


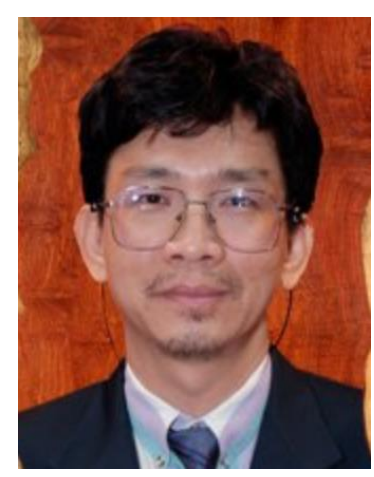

ASSOC. PROF. DR. CHOONG KOK KEONG

Presentation Title:

\section{Evolvement of New Precast Retaining Wall Design: Malaysian Experience}

\section{Brief Resume:}

Associate Professor Dr. Choong Kok Keong is an academic staff at School of Civil Engineering, Universiti Sains Malaysia. Currently, he is holding the position of deputy dean (research, postgraduate \& networking) of School of Civil Engineering. Dr. Choong specializes in the field of computational analysis of shell \& spatial structures. He also collaborates with industry in areas of precast concrete technology, cold-form steel structures, dynamics of structures and tensioned fabric structures. Dr. Choong is a registered professional engineer with Board of Engineers, Malaysia. 
JСロNTES

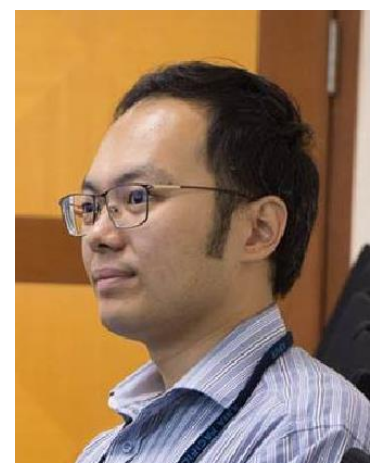

DR. LAI NAI SHYAN

\section{Presentation Title:}

\section{Towards Silicon MOS Quantum Dots Spin Qubits}

\section{Brief Resume:}

Dr. Lai Nai Shyan was born in Seremban, Malaysia, is currently a Senior Lecturer at School of Engineering, Asia Pacific University of Technology \& Innovation, working in the area of micro- and nano-electronics. He received his B. Eng. (Hons) in Electrical Engineering (2007) and Ph.D. in the field of Silicon-Based Nano-electronics and Radiation Detectors (2012) from University of New South Wales.His main research interest includes semiconductor micro- and nano-fabrication, quantum dot devices, low temperature (milli-Kelvin) measurements, single electron transistors, quantum computation and silicon microdosimeters. Over the past few years, he was involved in multi-million dollar projects funded by the Australian Research Council, U. S. National Security Agency and U. S. Army Research Office. His work has resulted into various notable technical publications in Nature Publishing Group. 


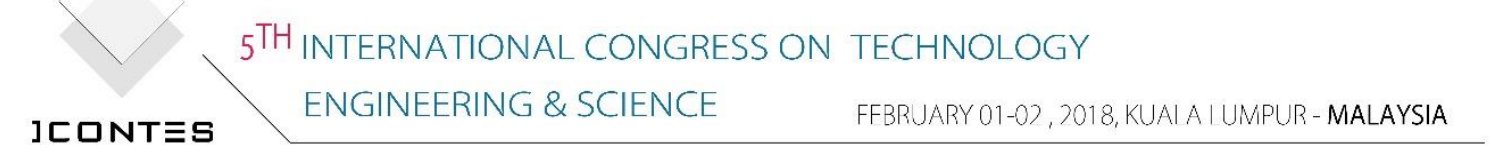

\section{Session Chairpersons}

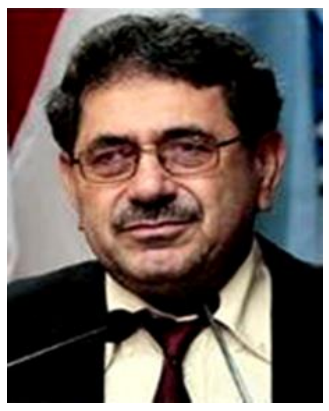

PROF. GHASEM D. NAJAFPOUR

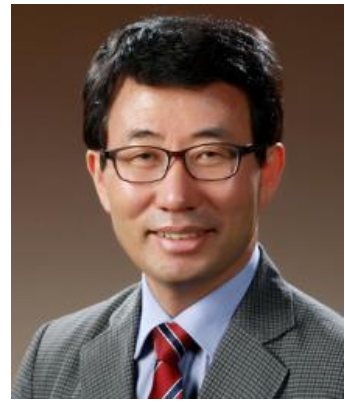

PROFESSOR KYO-SEON KIM

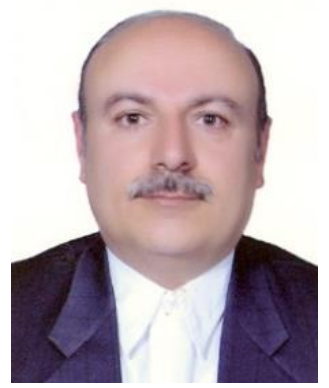

PROFESSOR SEYYED MOHAMMAD GHOREISHI

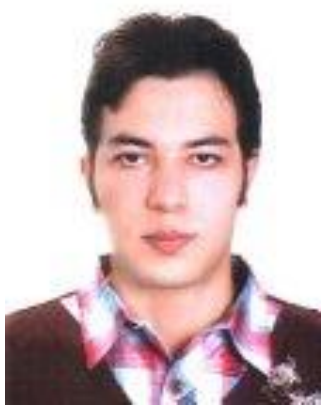

DR. M. BATAEE

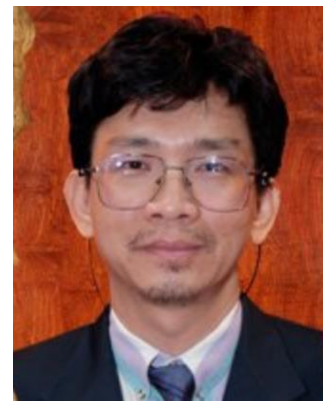

ASSOC. PROF. DR. CHOONG KOK KEONG

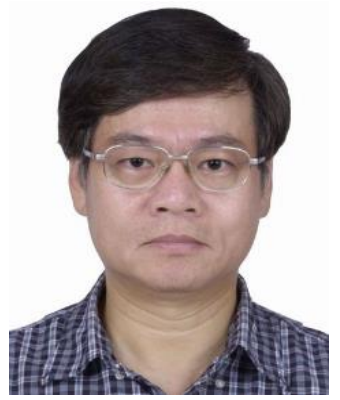

PROFESSOR YEONG-TARNG SHIEH

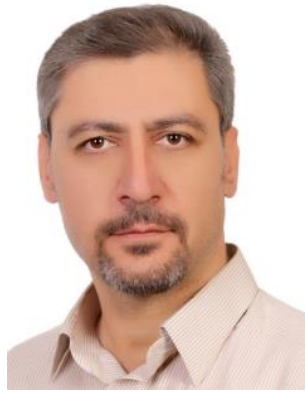

$$
\begin{aligned}
& \text { DR. ALI HASSANI } \\
& \text { JOSHAGHANI }
\end{aligned}
$$

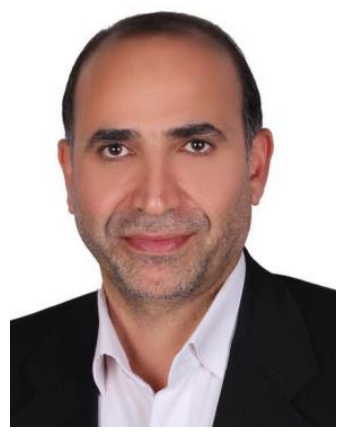

DR. HOSSEIN MAZAHERI

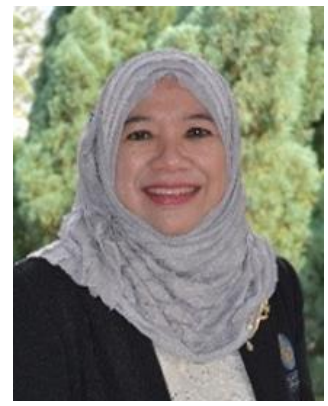

PROF. DR. NORANI MUTI MOHAMED

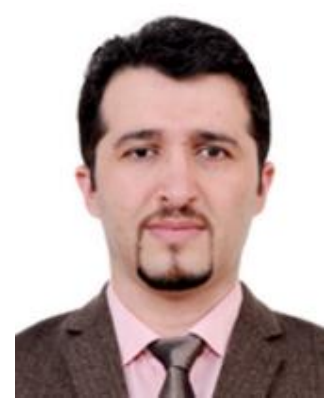

DR. SAEED KAKOOEI

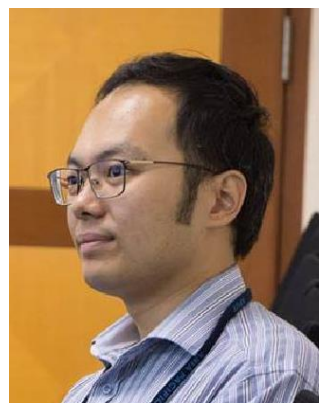

DR. LAI NAI SHYAN

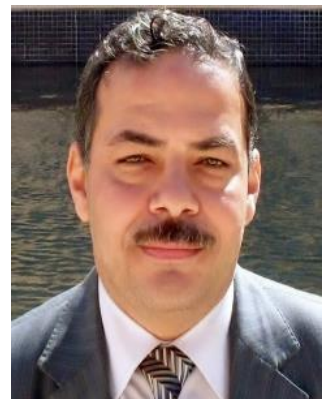

DR. KHALED ELGENDY 


\section{Congress Executive Members}

Dr. Saeid Kakooei

Dr. Ali Hassani

Mr. Mahdi Feizbahr

Dr. Robabeh Asadpour

Dr. Mahmood Bathaee

Mrs. Murni Miru

Mrs. Aisya Azlin Binti Azizuddin

Mrs. Audree Leanne Co 


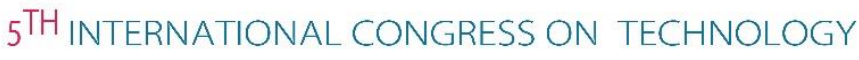

]СロNTES

Title Page

In Silico Analysis of Major Proteins from Salmonella Typhimurium Biofilm ................... 1

Detection and Classification of Short and Long Duration Disturbances in Power System .. 2 A New Topology for Multilevel Inverters with Symmetric and Asymmetric Configurations

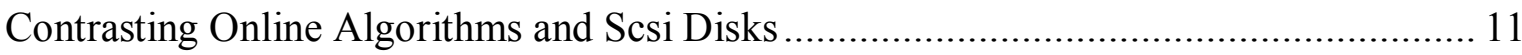

Automatic Testing Method of Mobile Applications for E-commerce ............................ 12

Effect of Sensory Electrical Stimulation onTremor: Comparison of Parkinsonian and

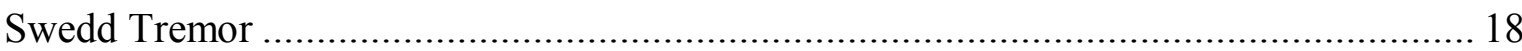

Controlled Temperature of Smart Solar Dryer by Smart Phone ..................................... 20

Using Wireless Sensors Monitor and Analyze Air Pollution System …......................... 28

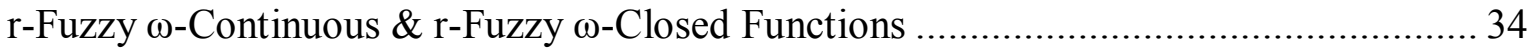

Introducing a New Object Function for Optimal Power Flow Problem .......................... 42

Chest X-ray Segmentation Using Cnn onSmall Amounts of High-variance Data............. 52

Applying Data Science Methods in Production and Geological Data Verification ........... 60

Application of Network Security Approaches to University Management ....................... 64

Geolectrical Equipment Research Activity in Laboratory of Exploration and Geothermal,

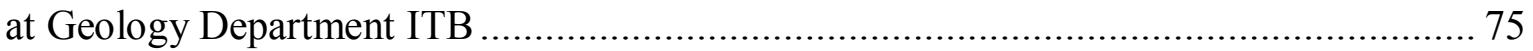

Novel Structure for Reactive Power Market by Considering Reactive Losses Caused by Active Power Flow

Early Usability Evaluation on User Centered Requirement Engineering Case Study: Web

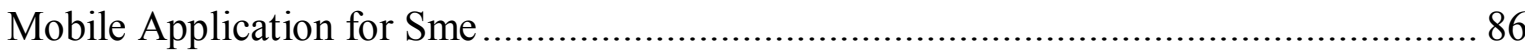

User Experienced Based Clustering for Opac Design .................................................. 99

ANFIS Fault Diagnostic Model for Turbo-Jet Engine.............................................. 105

Optimal Scheduling of Electric Vehicles Parking Lot in a Smart Distribution System ... 120

Estimating Media Impact of Municipal Goverment Planning Using Topic Model ......... 121

Evolutionary Trends in Palynological Studies of Family Polygonaceae from Pakistan .. 126

The Efficacy of a Macroalgae Gracilaria Corticata on Growth Parameters and Vibriosis

Resistance in Shrimp Litopenaeus Vannamei .......................................................... 135

Evaluation of Heterosis for Heat Tolerance in Wheat …........................................... 136

Integrated Use of Nitrogen and Phosphorus Improved Sunflower Yield, Nutrient Uptake and Use Efficiencies in Rainfed Areas

Comparative Efficacy of Different Indigenous Drugs Against Paramphistomosis from

Pakistan 


\section{$5^{\text {TH }}$ INTERNATIONAL CONGRESS ON TECHNOLOGY}

JСロNTES

Title Page

Studying Effects of Seed Different Moisture at Hand Picking onSeed Germination Maize

(Zea mays l.) Variety Hybrid S.c 704. 145

Antimicrobial Activity of Poly Lactic Acid Films Containing Ziziphora Clinopodioides Essential Oil Against Bacillus Subtilis and Salmonella Typhimurium 146

Antibacterial Activity of Lactobacillus Casei on Growth and Enterotoxin Production of Staphylococcus Aureus 29213

Inhibitory Activity of Lactobacillus Acidophilus Against Growth and Enterotoxin Production of Staphylococcus Aureus

The Contribution of Extension Service Delivery on Agricultural Based Adaptation Practices to Climate Change Impact in Nigeria.

Effect of Wavelength and Organic Agriculture on Reduce Oxalate Accumulation in Tomato Fruit (Lycopersicon esculentum) Mill.

Potassium Phosphite Enhanced Defense Responses in Downy Mildew- Infected Cucumber (Cucumis sativus L.) Plants

Impact of the Introduction of Fish in Al Rahad Turda on the Fishermen and Fishing Activity.

Non-toxic -naturally Control Methods for Sustainable Control of Main Pests in Olive

Farms in Egypt.

Impact of Silver and Copper Nanoparticles on Fusarium Solani F. Sp. Phaseoli Causal Bean Dry Root Rot Disease.

Turning Constitutive Core Promoters into Tunable Tissue Specific Promoters by

Combining Functional Analysis Coupled with Bioinformatic Tools

Study of the Effect of Pinus Gerardiana Seed onBlood Glucose and Oxidative Stress in

Serum and Liver in Diabetic Rats. 170

Cocoa Maturity Colors Kit (Co-MaCK) Derivation Using Digital Image Processing

Approach

Effect of Aflatoxins onInfant Growth

The Role of Nutrition in the Prevention of Drug Addiction

In Vitro Determination of a Coated Urea Solubility Over Time

P-wave Reflection Coefficient for a VTI/VTI Interface.

Estimation of Depth Values Using Multispectral Worldview-2 Satellite Imagery-

Feasibility Study: Hendorabi Island, Persian Gulf ..... 178

CFRP Cables: The Future Material for Cable Structures. 186

The Development High Strength of HDPE Fiber Reinforced Cement Mortar 


\section{$5^{\text {TH }}$ INTERNATIONAL CONGRESS ON TECHNOLOGY}

JСロNTES

Title Page

Sector-specific Routines and Curricula for Eco-engineering in the Mediterranean 202

A Laboratory Modeling Investigation of Vegetative Rod Diameter Effects on Fr. No. in

Sediment Flow Conditions 205

Fouling Characteristics of Nanofiltration (NF) and Reverse Osmosis (RO) Membranes for Reuse of Organized Industrial Zone Wastewater 216

Effect of Hydrophobisation onDurability Related Properties of Concrete with Expanded Perlite 218

Solar Passive Architecture. 220

Determination of Optimal Tuning Parameters for Tuned Mass Dampers Under Earthquake Excitation. 222

Effect of Enhanced Road Marking in Speed and Lateral Position 224

Performance of Traffic Contraflow Strategy in Malaysia 225

A Sensitivity Analysis for Improvement of Stormwater Interception Ratio Estimating of Vegetative Swale LID Facility .... 226

The Development Strategy of Ornamental Brick Shell: A Materialization of

Environmentally-Friendly Materials....

Kinetic Modeling of Co-digestion of Food Waste with Sewage Sludge: A Review..... 230

Can Leca Be Used to Improve the Thermal Performance of an Extensive Green Roof? . 231

Phosphorus Removal from Landfill Leachate by Microalgae. 233

Assessment of Landslide Vulnerability : Case of Small and Medium Sized Cities 244

Are Intersections of the Capital of Bangladesh Performing Well? A Factor Based Analysis

Applicability of Landsat Tm and Modis Images for Soil Salinity Mapping of Coastal Bangladesh

Effect of Graphene Oxide on Pull Out Strength of Hardened Concrete 250

Selection of a Membrane Module Treating Organized Industrial Zone Wastewater with a Membrane Bioreactor (MBR) 263

Salinity Assesment by Using Gis Model to Explore Safe Water Options in South Coast of Bangladesh 264

The Effect of Inlet Baffle Position in Improving the Efficiency of Oil and Water Gravity Separator Tanks 266

Numerical Investigation of One-way Reinforced Concrete Slab Subjected to Underwater Explosion..... 267

Properties of Mortars Incorporating Brick Dust. 273 


\section{$5^{\text {TH }}$ INTERNATIONAL CONGRESS ON TECHNOLOGY}

]СロNTES

Title Page

The Analysis of Skin Friction onPrebored and Precast Piles 274

Analysis of Soil-pile Systems Subjected to Dynamic Loads 276

Engineering Education and the Differential Effects of Student-Level Factors onScience and Mathematics Achievement: A Study Using TIMSS 2015 Data of Singapore 279

Experimental and Numerical Investigation on Fair-faced Concrete 293

Comparison of Petrophysical Relationship for Soil Water Content Estimation at Peat Soil Using GPR Common-Offset Measurements 305

Seismic Retrofit of Flat Plate and Flat Slabs Using Ferrocement 317

Utilization of Agro-Waste in Cement Mortar 327

Numerical Evaluation of One-way Reinforced Concrete Slab Subjected to Air Blast Loading 328

Production of Fluid Gas Desulphurization Wastes as a Composite Filler 330

Assessment of Various Waste Resources for the Stabilization of $\mathrm{Pb}$ Contaminated Mine Tailings.

Preliminary Study onThe Lyso:ce/bcf-12 Phoswich Detector for Simultaneous Detection of Beta and Gamma Radiations .....

Photosynthesis Assisted Anaerobic Digestion: A Novel Technique for Wastewater Treatment and Highly Pure Methane Production 340

Effect of Reaction Time on Performance of Aerobic Granular System

Vegetables Waste Caused by Horticultural Activity in Bandung City

Performance of Asphaltic Concrete Containing Black Rice Husk Ash at Different Aging

Numerical Modeling of Mechanical Behavior Concrete Slabs Reinforced by FRP

Materials

Snow Landscape and Design Plants

Investigation of the Effect of Openings on the Behavior of Arched Concrete Shear and Reinforced Walls Using FRP Fibers.

Numerical performance of different interpolation functions in simulation of dam breaking flow using incompressible SPH method

Recovery Prediction of Thymol from Ajwain Using Supercritical $\mathrm{CO}_{2}$ Via Broken and Intact Cells and Shrinking Core Models 358

Development of Composite Catalyst and its Catalytic Performance in FCC Cracking ... 388

[Bis(2,2'-bipyridine)(Salphen)ruthenium(II)] Complexes as Anticancer Agents 389

The Novel Compound Shows Potent Anti-Human Cytomegalovirus Activity 390 


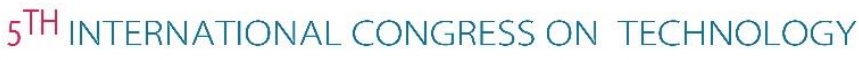

JСロNTES

Title Page

Study of Production of Aromatic Compounds by Different Process Configurations in a Crude Oil Refinery 391

Preparation of Narrower 1-D Nanostructured Tungsten Oxide Thin Film by Precursor Feed Rate Control 392

Growth of 1-D Nanostructured $\mathrm{MoO}_{\mathrm{x}}$ Thin Films by Flame Vapor Deposition Process . 394 Cobalt Phosphate Oxygen Evolution Catalyst for Efficient Photoelectrochemical Water Splitting

Reflectance Spectrophotometric DNA Biosensor Based on Metal Complex Intercalator 398 Surface Characterization of Oil-carbonate Rocks Interaction for Enhanced Oil Recovery 400

Synthesis of Efficient SCR Catalyst for Lean Burn Nox Emission Control 401

In Vivo and in Silico Toxicity Assessment of Hexane Rhizome Extract from Black Turmeric (Curcuma caesia Roxb).

Copper(II), Palladium(II) and Zinc(II) Complexes of $\mathrm{O}^{\wedge} \mathrm{O}$ and $\mathrm{N}^{\wedge} \mathrm{S}$ Donor Ligands as Anticancer Agents.

Photocatalytic Performance of $\mathrm{H}_{6} \mathrm{P}_{2} \mathrm{~W}_{18} \mathrm{O}_{62} / \mathrm{TiO}_{2} /$ Beta Zeolite Nanocomposite in the Degradation of Methyl Orange. 404

Effect of the Structure on the Binding of Nickel Schiff Base Complexes to DNA 405

An Investigation onPerformance of Coupled Newly Constructed Wetland with Microbial Fuel Cell for Industrial Wastewater Treatment and Bioelectricity Generation: Batch vs Continuous Flow. 406

Phenotypic and Genotypic Characterization of a Novel Soil-isolated Strain of Pantoea

Genus with High EPS Production.... 407

Enhanced Microwave Extraction of Bioactive Compound Curcumin from Turmeric

Production of Bassia (Bassia Longifolia) Oil-based Polyol via Epoxidation and Ring Opening .

Synthesis and Characterization of Vegetable Oil-Based Biopolymer for Decorative Coating

New Spectrophotometric Determination of Zn (II) in Some Plants and Pharmaceutical Preparations in Presence of Surfactant

Safety Modeling in Gas Delivery of Liquefied Natural Gas (LNG) to Cars

The Production of Biofuels from Waste Almond Shell (Biomass) by the Following Process

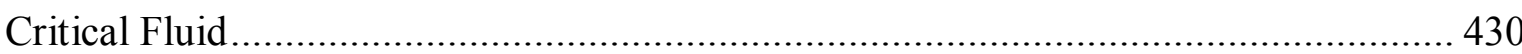

Industrial and Raw Knots of the North Within Social and Economic Interactions..... 


\section{$5^{\text {TH }}$ INTERNATIONAL CONGRESS ON TECHNOLOGY}

]СロNTES

Title Page

The Contribution of Extension Service Delivery in Agricultural Adaptation to Climate Change Impact in Nigeria 433

Critical Factors Affecting Work Life Balance of Managerial Women - An Empirical Study with Reference to Tamilnadu, India.

Analyzing the Impact of Organizational Justice on Organizational Citizenship Behavior with the Moderating Role of Power Distance

Banga Crossing Massacre and the Saguibin Festival: The Paradigmatic Philosophical Influence of Levinas' Ethico-Political Milieu to Women Local Governance and Political Affairs

Apoliticism in the Progression of Leadership Triads as Depicted in Augustine's Literary Activity and Philosophy of Education

The Diverging Clashes of Neuro-philosophical Viewpoints on Qualitative Properties of Consciousness 458

Online Shopping Behaviour Among College Students in Tamilnadu, India 459

Requirement Prototyping for Student Admission System: Cases for Junior High Schools in Indonesia

Myth of the Queen of the South Sea and Kasunanan Palace as a Tourism Attraction of Baluwarti, Surakarta

Lady Mahin, Shapour and the Wise (Yungi Analysis of the Wise in Khosrow and Shirin Poetry of Nezami Gangavi in Iran)

A Review on Alternate Theories of Motivation Adopted by SLA Researchers

Performance Goals, Mastery Goals and L2 Motivation (A Brief Review). 484

Characteristic Analysis of Bi-Axial Stretching PVDF Thin Film 489

Bayesian Planning of Progressive Simple Step-Stress Accelerated Life Test for Birnbaumsaunders Lifetime Distribution Under Type I Right Censoring 491

Investigation Titanium-graphene Nanocomposite Fabrication by Powder Metallurgy.... 511 Energy Absorption Capability and Failure Modes Reinforced Composite Hexagonal Tubes

MHD Mixed Convective Heat Transfer in a Double Lid-Driven Oblique Cavity Filled with Ferrofluids 513

The Development and Testing of Wind Tunnel Arduino Based System (Windtabs) ...... 521 Investigation and Performance Analysis of Innovative Solar Still for Small Family Potable Water Requirement

Paper Giant Magneto-Impedance and Magnetic Properties of Co-rich Crossed Amorphous Microwires: Focus on Angular Dependence ...... 530 


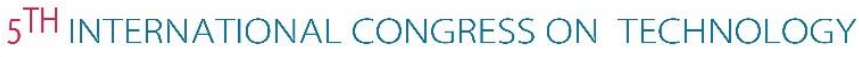

$\underline{\text { Title }}$ Page

Ultrasonic Wave Propagation in Aerospace Structures: Highly Efficient Simulation with a Minimal Model 531

Remaining Useful Life Prediction of Drill String Using Fuzzy Systems and Cumulative

Damage Theory 536

Gear Fault Analysis Based on Acoustic Signal and Least Square Support Vector Machine

Experimental and Numerical Study of a Double Pass Solar Air Heater 538

Electrodeposited Li- Doped ZnO Nanowire for Photovoltaic Applications 539

Effect of Nanosilica onCompressive Strength of Mortar with Using Silica Sand and Volcano Sand......

Gold Nanoparticle-based Colorimetric Biosensors for the Detection of Glycated

Hemoglobin

Nanofabrication of Emulsified BSA-MWCNTs Nanohybrids.

Synthesis and Self-Assembly Process of Aqueous Silica Hybrids and Their Application for Sustainable Environmental Remediation 551

Investigation of Mechanical Properties of Borophene: A Molecular Dynamics Simulation Study 552

The Thermal Degradation Kinetic of ABS/OMT Nanocomposites 554

Formulation and Evaluation of Surface Functionalized Nanoparticles Enclosing Myelin

Basic Protein for Treatment of Multiple Sclerosis 555

Structural and Electrical Characterization of $\mathrm{SrCeO}_{3}$ and $\mathrm{Sr}_{2} \mathrm{CeO}_{4}$ :a Comparative Study560 Adsorption of Chromium from Aqueous Solutions by Polyaniline/Melamine/ $\mathrm{Al}_{2} \mathrm{O}_{3}$ Nanocomposite 563

Structural, Optical and Electrical Properties of Al-Mn Co-Doped $\mathrm{SnO}_{2}$ Nanoparticles Synthesised by Sol-Gel Process 564

Fabrication of Cellulose Acetate Supported Alkali Metal Functionalized Ionic Liquid Membrane for Electrochemical Measurements Using Impedance Spectroscopy .... 575

Interfacial Damage in Phase Change Materials Tuned Optical Structures

Electrospinning and the Scaling Law Model for Beaded Fiber and Smooth Fiber from Poly(Vinyl Alcohol) (PVA) .

Enhanced Shear Thickening Effect of Silica Nanoparticle Suspension by Using Carbon

Nanotube for the Body Armour and Energy Absorbing Applications 588

Preparation and Characterization of Vitamin B Complex Infiltrated Oxidized Nanocrystalline Porous Silicon for Biosensor Application. 590

Formulation, Evaluation and Optimization of Metronidazole Sr Buccal Tablet for Gingivitis Using Artificial Intelligence. 


\section{$5^{\text {TH }}$ INTERNATIONAL CONGRESS ON TECHNOLOGY}

JСロNTES

Title Page

The Binding Energy of Deformed Super Heavy Nuclei with $\mathrm{Z} \geq 105$ 601

DFT Electron Transport Study of Ferrocene Molecule Along with Thiol and Amine Anchors

Preparation and Characterization of Amino Acid - Modified PVC Adsorbing Film for Methyl Red Removal 606

Synthesis of 5-Substituted $1 H$-Tetrazoles Catalyzed by Zeolite Modified with Copper Oxide Nanoparticles 611

Design of Damage-Free Oxide Etching Chamber for 450mm Process Technology ... 616 Investigation of Structural and Electrical Properties of Manganese Doped ZnO Varistors Prepared from Nanopowders

Transitions of Nanosized Magnetite in Glass-ceramics.

Strain Effects and Symmetry Mismatch at Heterointerfaces in $\mathrm{BiFeO}_{3} / \mathrm{LaFeO}_{3}$

Superlattices

Production of Graphene Reinforced Nylon 6.6 Nanofibers by Electrospun Method. 625

Chemical Analysis and Mechanical Properties of Epoxy Adhesives of Graphene

Reinforced Nylon-6.6 Nanomats

Radical Scavenging Abilities of Carbon Nanotubes and Their Applications

Structural and Electrical Characterizations of Double Perovskite System $\mathrm{Sr}_{2} \mathrm{CoMoO}_{6-\delta}$

Impedance Studies onAluminium Doped $\mathrm{SnO}_{2}$ Nanoparticles Synthesised by Sol-gel Process.

Application of forward Osmosis Method in Recovery of Refined Sewage with Potassium

Chloride. 640

Color Change Analysis Study Using Thermos-chromic Pigment 646

Study on the Photomechanical Effects Caused by Short Pulse Width Lasers 648

Preyssler Heteropolyacid: A Green Co-reducing Agent in the Bio-synthesis of Ag Nanoparticles in the Presence of Chaetomorpha linum Seaweed. 650

Application of Forward Osmosis Method in Recovery of Refined Sewage with Magnesium chloride.

Biocompatible and Biodegradable Drug Delivery System for Tumor

Microenvironment-responsive Triggered Release.....

A Nano-structured Vanadium (V)-Quercetin Complex: Synthesis, Characterization and Applications 663

Effects Of Corrosive Environment To Concrete Structures Performance With Multilayered Carbon Nanotubes 664 


\title{
Geolectrical Equipment Research Activity in Laboratory of Exploration and Geothermal, at Geology Department ITB
}

\author{
Prihadi Sumintadireja \\ Geology Department, Faculty Earth Sciences and Technology, Institut Teknologi Bandung (ITB) \\ (Phone: +62-22-2511159; Email: prihadi@gc.itb.ac.id) \\ CPI: http://procedia.org/cpi/ICONTES-5-2111194
}

\begin{abstract}
The Exploration Geology and Geothermal Laboratory (LEGG) was established in June 2017 as a research institution under the Faculty of Earth Science and Technology (FITB), Institut Teknologi of Bandung (ITB). As indicted by the three principle of higher education (Education, Research, and Community Services), the research lab has a goal to conduct researches on applied geosciences and modeling surface and subsurface geosciences data for exploration, geological hazard mitigation, and environmental geosciences and to publish the results both in national as well as international level. The lab specializes in creating a geological model from surface and subsurface data in order to solve real world problem.

LEGG's research activities that was done in between 2005 - 2017 are funded by ITB's Research and Community Services Institute in addition to funding from petroleum and geothermal industry. The researches done in several stages that is listed below: 1.) Lab scale geo-electric measuring device prototype development, 2.) Field scale geo-electric measuring device development, 3.) Field scale measurement simulation, 4.) Environmental geoscience implementation and 5.) Petroleum industry implementation.

This paper is meant to highlight the LEGG's success story of more than 10 years of researching geoelectric acquisition and its implementaiton in the industry. The fruit of the research is LVG GLS, newly developed geoelectric acquisition instrument, that could record vast amount of higher quality data in shorter amount of time. Latest version of the device has 120 channels which means it has almost twice wider coverage and could be used to map three dimensional subsurface configuration quicker compared to any previous version.
\end{abstract}

Keywords: Current and potential electrode, mise-a-la-masse, R\&D, LEGG

\section{Introduction}

Exploration and Geothermal Laboratory (LEGG), previously known as Volcanology and Geothermal Laboratory (LVG) since 2004, was founded in June 2017. In alignment with Institut Teknologi Bandung's (ITB) mission as a higher education institute (Education, Research, and Community Services), the research group is directed to: 


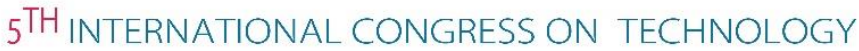

]СロNTES

1. Conduct researches on applied geoscience,

2. Develop modeling algorithm that could be well utilized in the industry, geological hazard mitigation and environmental geoscience,

3. Publish the results in national and international level.

Research activities from 2005 - 2017 was funded by the Research and Community Service Institute in combination with co-operation with the petroleum and geothermal industry. One of the lab's prominent product is a geo-electric measuring device specialized for mise-a-lamasse (MAM) method that could enable faster acquisition of higher data quality. Over the years, development of the measuring device could be classified into several different step as shown in the rest of this paper.

\section{Phase I: Lab Scale Geo-Electric Measuring Device Prototype Development}

The research started by designing a hardware for data logging. A logger is used to manage the data by directly storing and sorting it. Figure 1 illustrate how the data logger works. The sensor records electrical current and temperature that goes through the device which then transferred to multiplexer where it could be pre - processed and compiled. Each logger is connected to four blocks of sensor that contains electrical current measuring sensor. The sensor blocks are equipped with additional components to handle reduction that is caused by resistance of copper wire. Thus information that is received by the data logger has been corrected and concluded as valid data.

Then the data that has been acquired will be stored in an external memory or directly to a workstation. An external memory is able to hold at least 64 kilobytes of data where each data only requires 1 byte of space. The time step for acquisition could be set through keypad on the data logger. Significant changes in each time step is calculated instead of storing the whole dataset in order to utilize the memory effectively.

This newly improved system is able to monitor differences in spontaneous potential without restraining the user. An automatic system has been installed to the microcontroller therefore the user does not have to be present by the device at all times during measurement. The user could simply download the data after a certain period of time.

The measurement device was also designed to be comprised of multiple channels in order to shorten acquisition time. Single current injection to the ground could be measured simultaneously by all 64 electrodes. Calculation algorithm embedded in the machine is able to adjust for geometric factor and directly process the data. [1] 
]CONTES

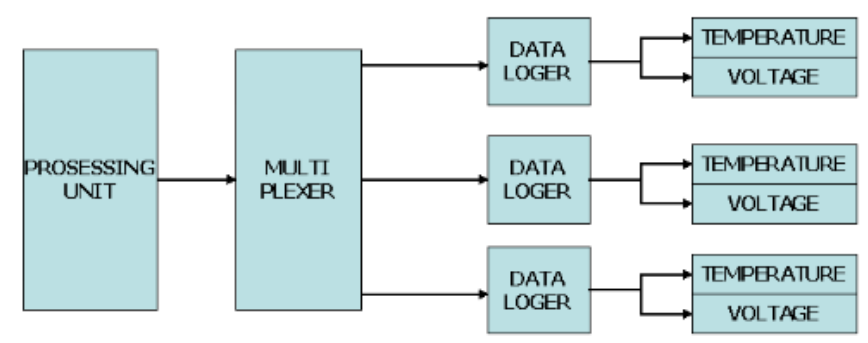

Figure 1. Logging workflow of the geo-electric measuring device.

The first phase of this research has successfully produced a device that could record data acquisitioned using the MAM configuration in several setting for spontaneous potential, instantaneous potential or resistivity measurement. However, full field implementation could not be done since the logger was still lacking of supporting equipment such as cables and electrodes (Figure 2). [2]

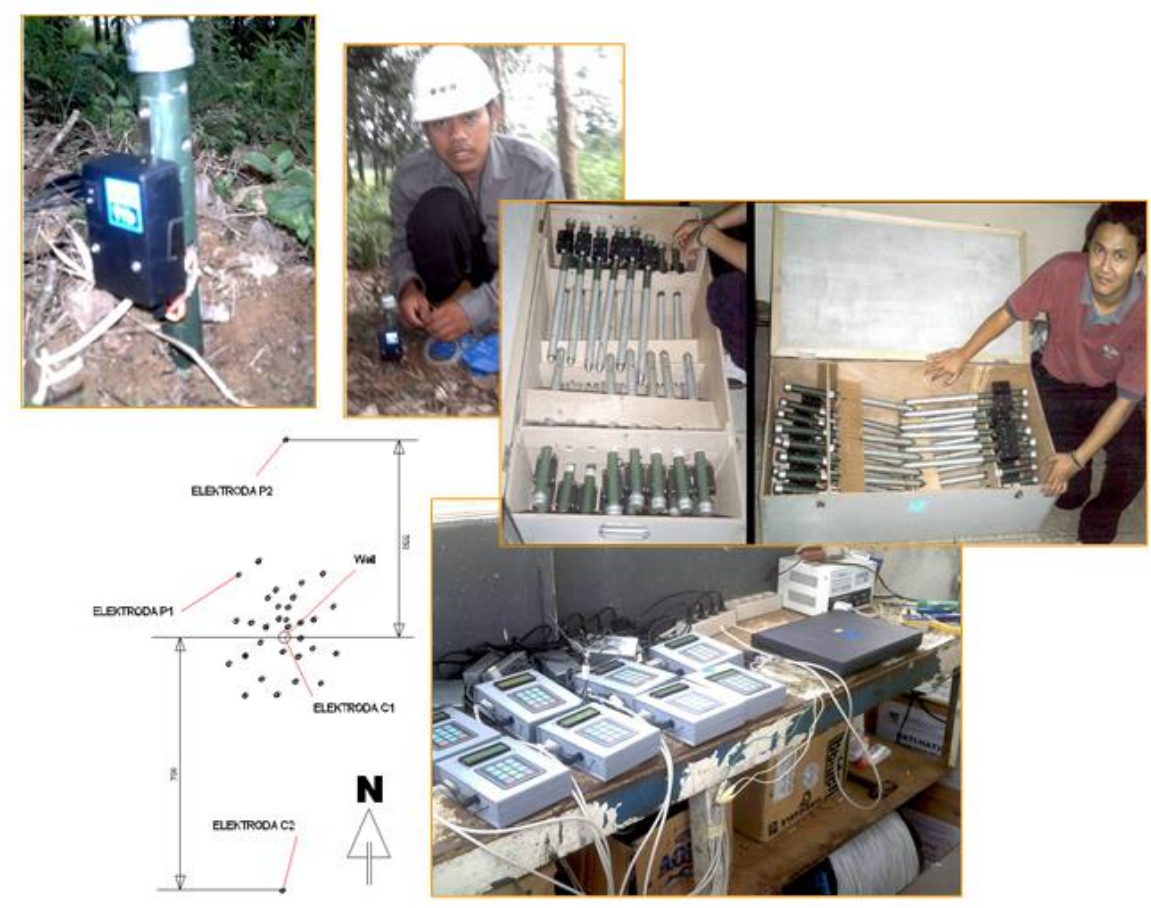

Figure 2. Prototype of geo-electric data logger.

\section{Phase II: Field Scale Geo-Electric Measuring Device Development}

The prototype from the first phase was not able to be tested for field measurement due to absence of cable and casing. In this second phase, the aim was to improve the device so it could be prepared for field condition (Figure 3). Analogue to digital converter (ADC) could measure up to 220 volts current however low voltage current of around $0-5$ volts' measurement should be avoided. Digital display for real time measurement has been added 
however direct communication to a computer has not been added. The use of Union T-60A multi-tester series is suitable to roughly measure voltage and currents.

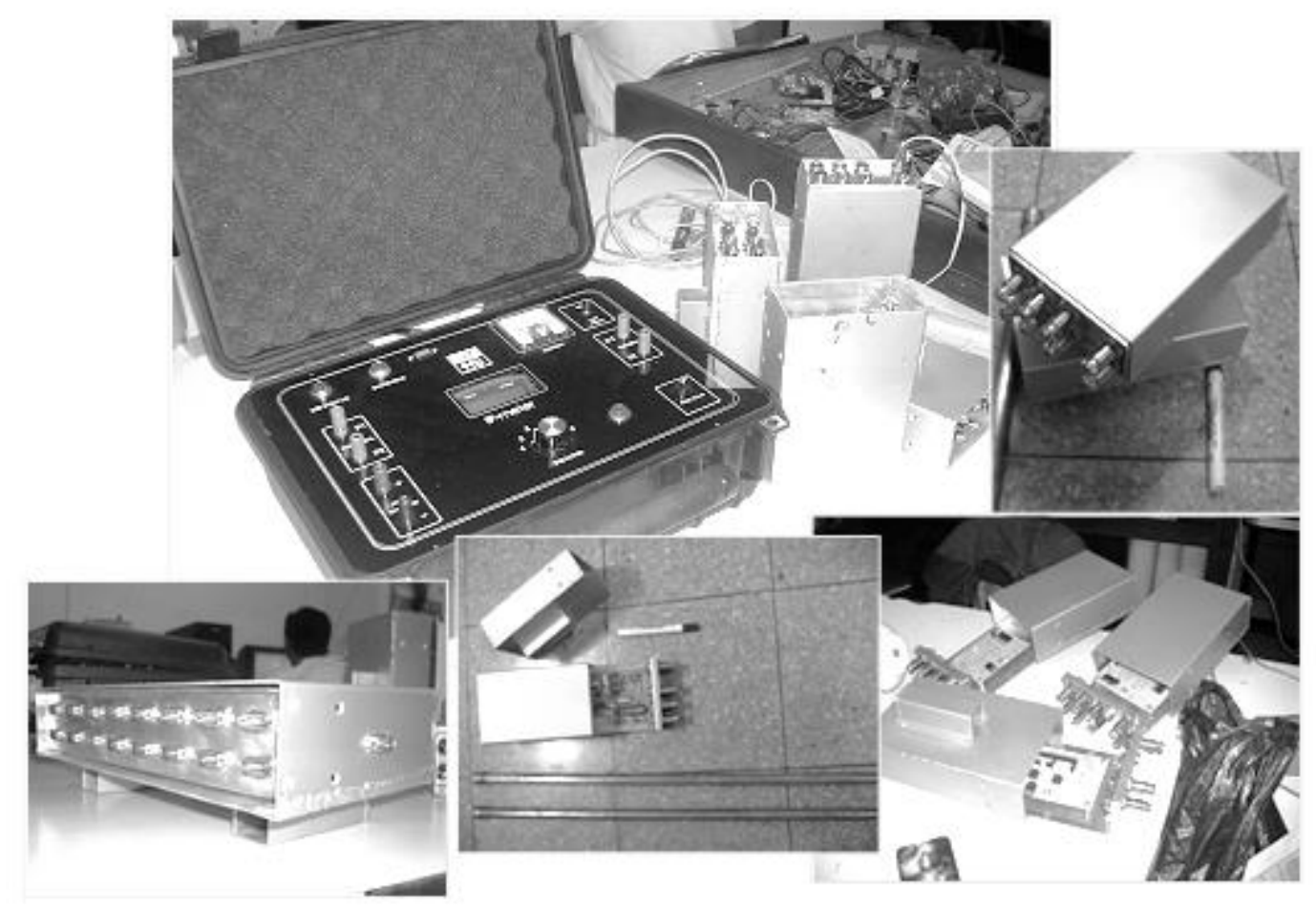

Figure 3. Field conditioning of the geo-electric measuring device.

\section{Phase III: Field Scale Measurement Simulation}

In the third phase, the device was developed even further. Now the device is comprised of one controller unit, one receiver unit, 64 electrodes, one current injector unit and 44 kilometers long cable (Figure 4). AC/DC electric transmitter of 220 volts was changed to 12 volts DC power into 220 volts of AC with $50 \mathrm{~Hz}$ frequency. Multi-meter receiver electric reader that consisted of Ampere-Volt-Ohm meter has also been installed to the device. The receiver also measures accuracy of the reading that is expressed in percentage. The instrument was tested with a resistor model shown in Figure 5. It was able to give a correct measurement as the designed model.

Then the prototype went through field measurement simulation. A dipping contour with flowing water was made by digging a pit into the ground. The electrodes were assembled in the pit based on the MAM configuration in order to record spontaneous potential and resistivity distribution (Figure 6). The acquired data (Figure 7) was able to produce a fluid flow model from the simulation. No significant problem arose during the simulation. 


\section{Phase IV: Environmental Geoscience Implementation}

In the fourth phase, the device was upgraded and tested in karst area to detect underground water movement. The field test was done in a karst that is located in Cijulang, West Java. The test was configured in MAM setting. Measurement from 64 electrodes was done in less than 15 minutes. Then the result could be stored directly into the computer in ASCII format using a VGA connection (Figure 8).

The measurement result (Figure 9) was able to delineate the underground river at the karst area. The low resistivity area was found to be in alignment with the interpreted fault lineaments. Calibrated with cave entrances, the underground river seems to flow in E-W direction.

\section{Phase V: Petroleum Industry Implementation}

Another field test was also done in an oil field. Kasikan field which is located in West Sumatra implemented cyclic steam stimulation where steam is injected in order to lower the oil's viscosity and increase its mobility. Resistivity is influenced by temperature and pore fluid content. [4] Hydrocarbon saturated reservoir in low temperature has a value between 4 $-10 \mathrm{ohmm}$ while the high temperature steam saturated reservoir is between $9-17$ ohmm. [3] [5]

Geoelectric acquisition using MAM configuration was done in between the injector and producer to monitor the steam distribution. Measurement prior the steam injection that reservoir fluid was flowing in NE-SW direction. Subsequent to the steam injection, area nearby the injector in the south increased toward the north. Periods after injection, the resistivity distribution turned back into a state similar before injection.

Data processing considered geometrical factor based on potential electrode located in the wellbores [6]. Three dimensional inversion model model workflow was programmed and adjusted to the geometric factor as well.

Then three dimensional resistivity distribution was utilized for an inversion based on the injector. Figure 11 illustrate measurement during injection. High resistivity value $(9-17$ $\mathrm{ohmm}$ ) represented the flow of steam that is moving toward NE directoin. Lower resistivity area $(4-9$ ohmm) represented hydrocarbon saturated reservoir that is not influenced by steam injection. The workover strategy could be determined based the flow direction that has been identified through geoelectric measurement. 

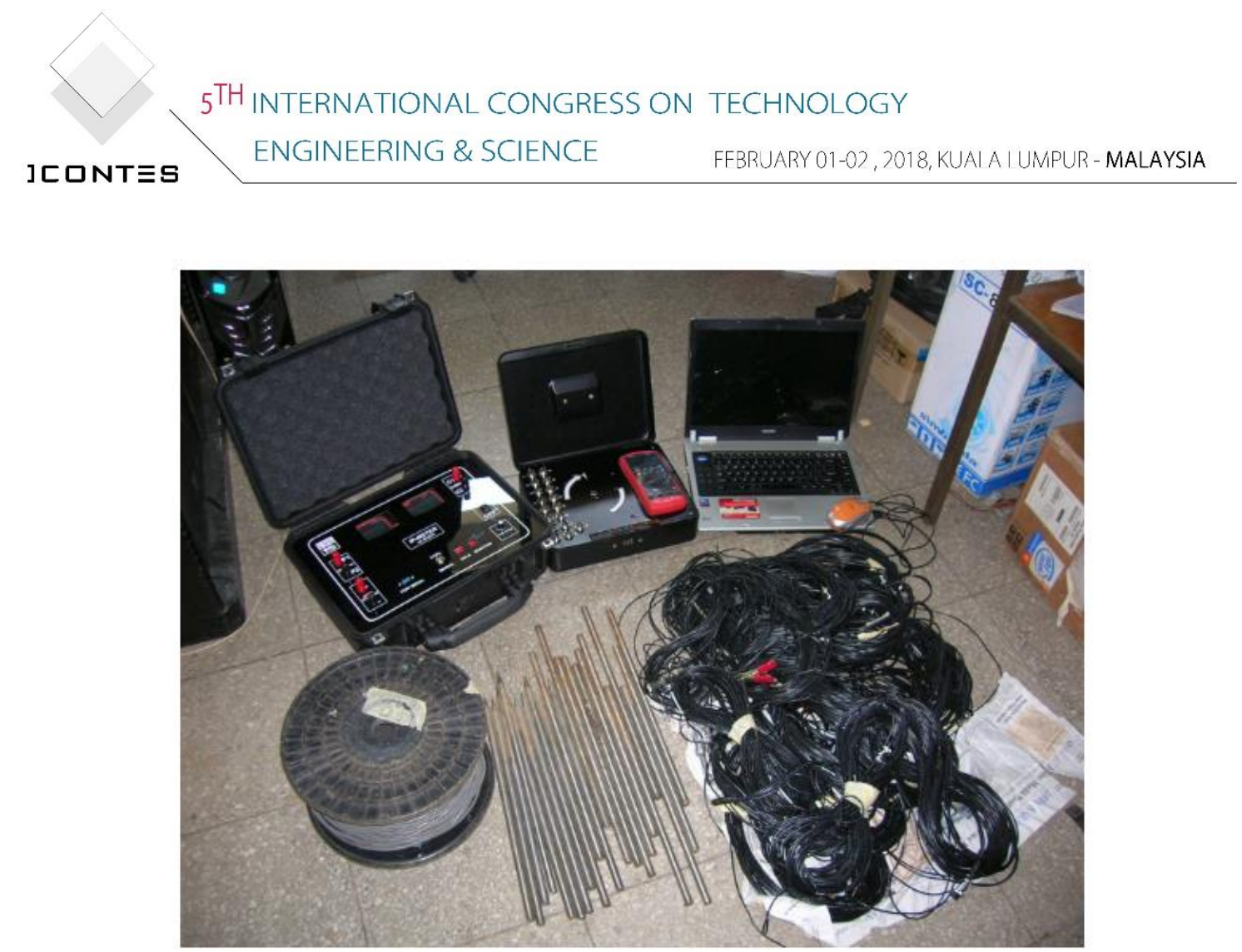

Figure 4. Complete set geo-electric measuring device for MAM configuration from the $3^{\text {rd }}$ phase.

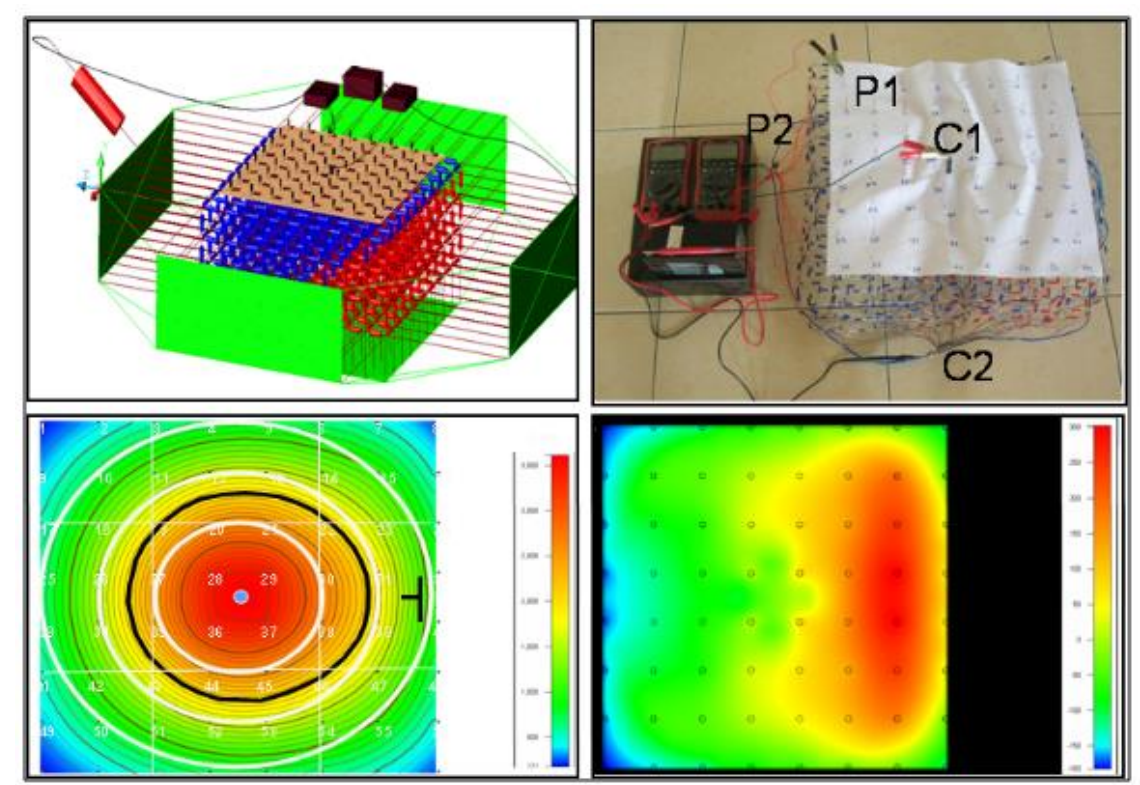

Figure 5. Measurement of resistor model from a slope layer. 


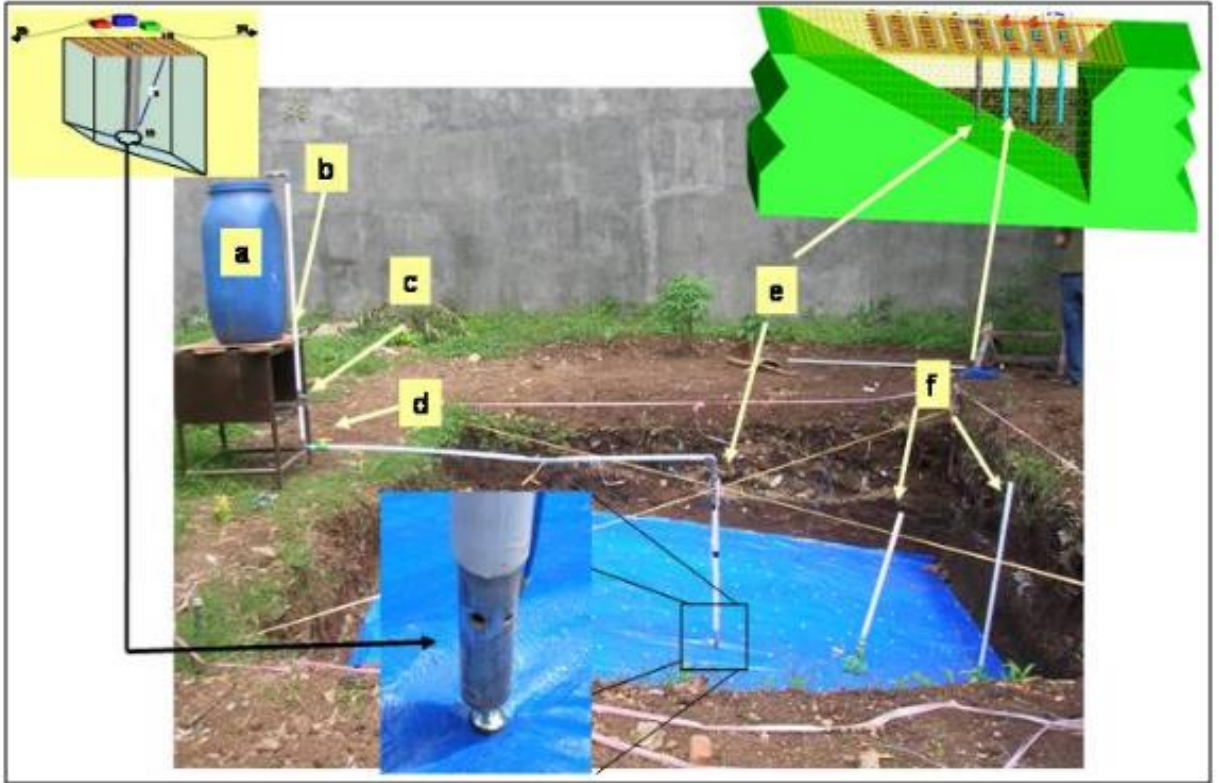

Figure 6. Measurement in dipping slope with flowing water simulation.
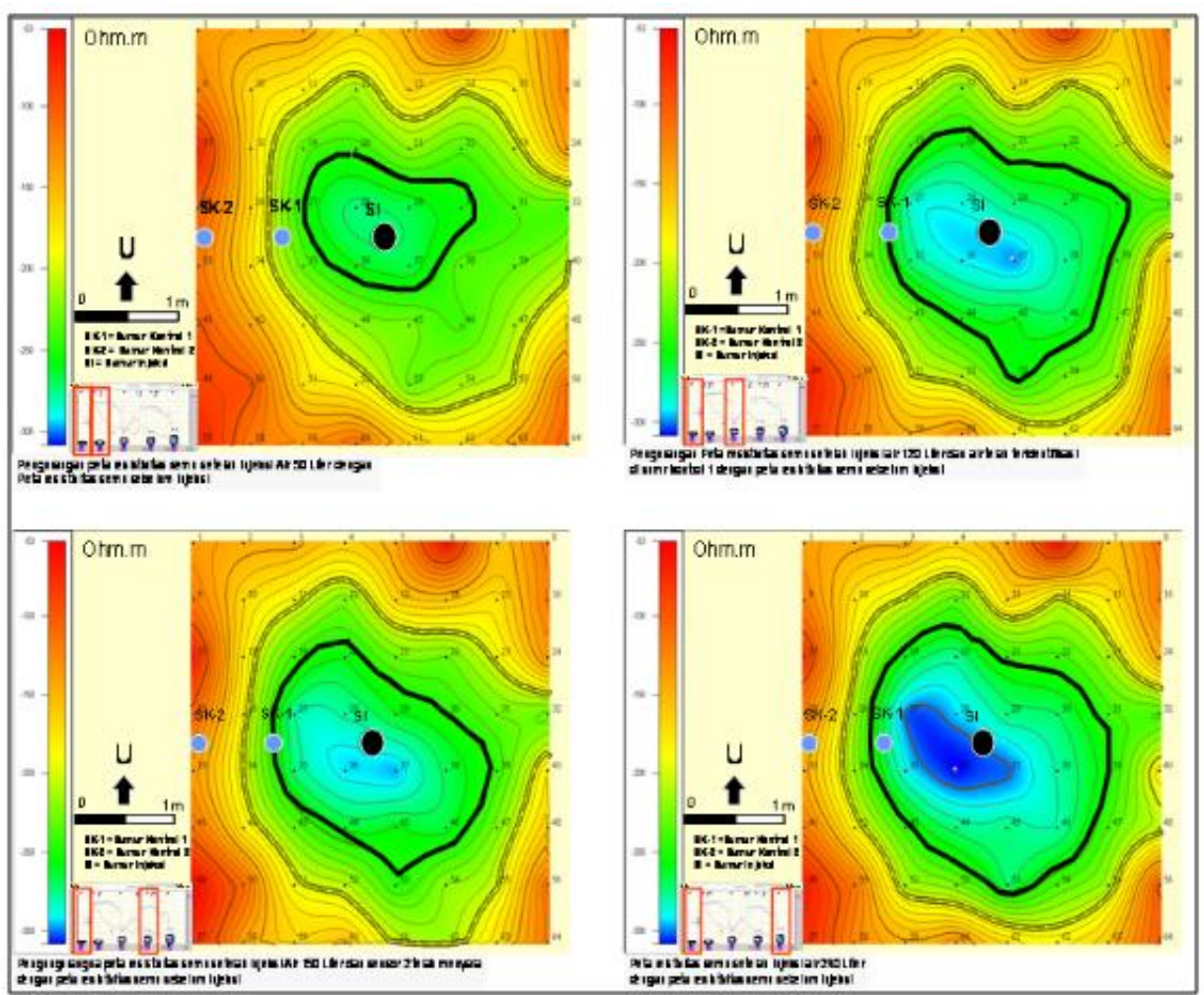

Figure 7. Measurement result from fluid flow in dipping slope simulation. 


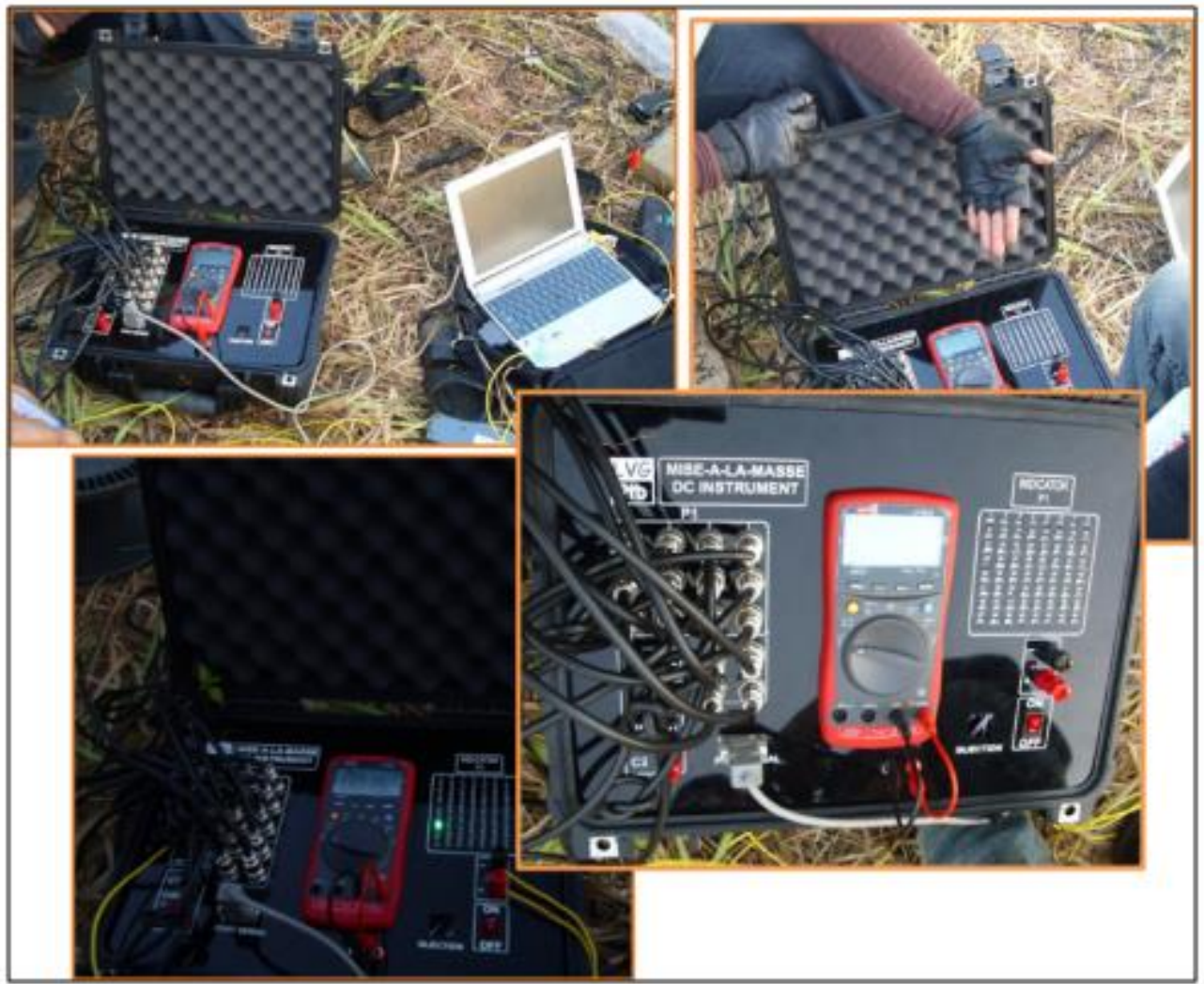

Figure 8. Field proofed geo-electric measuring device with computer connection.
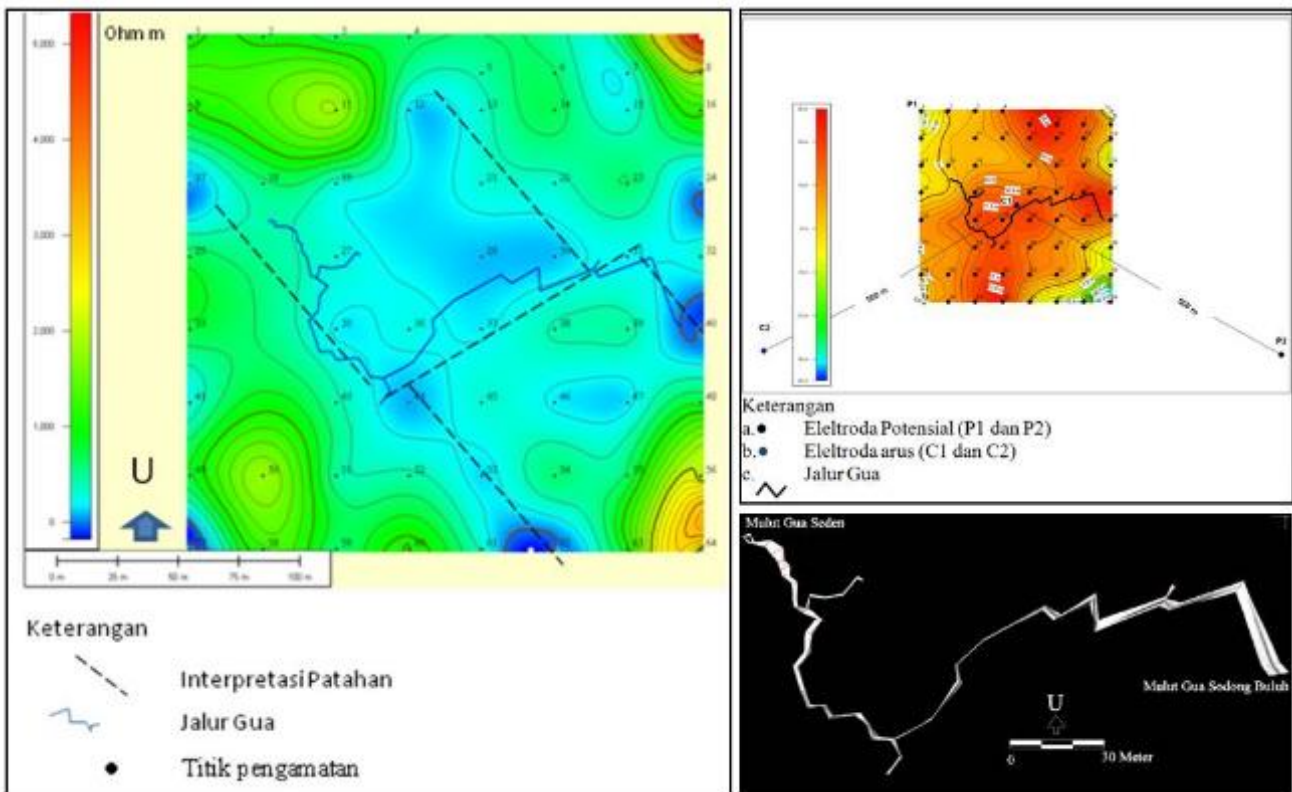

Figure 9. Underground river detection using geo-electric ini MAM configuration. 

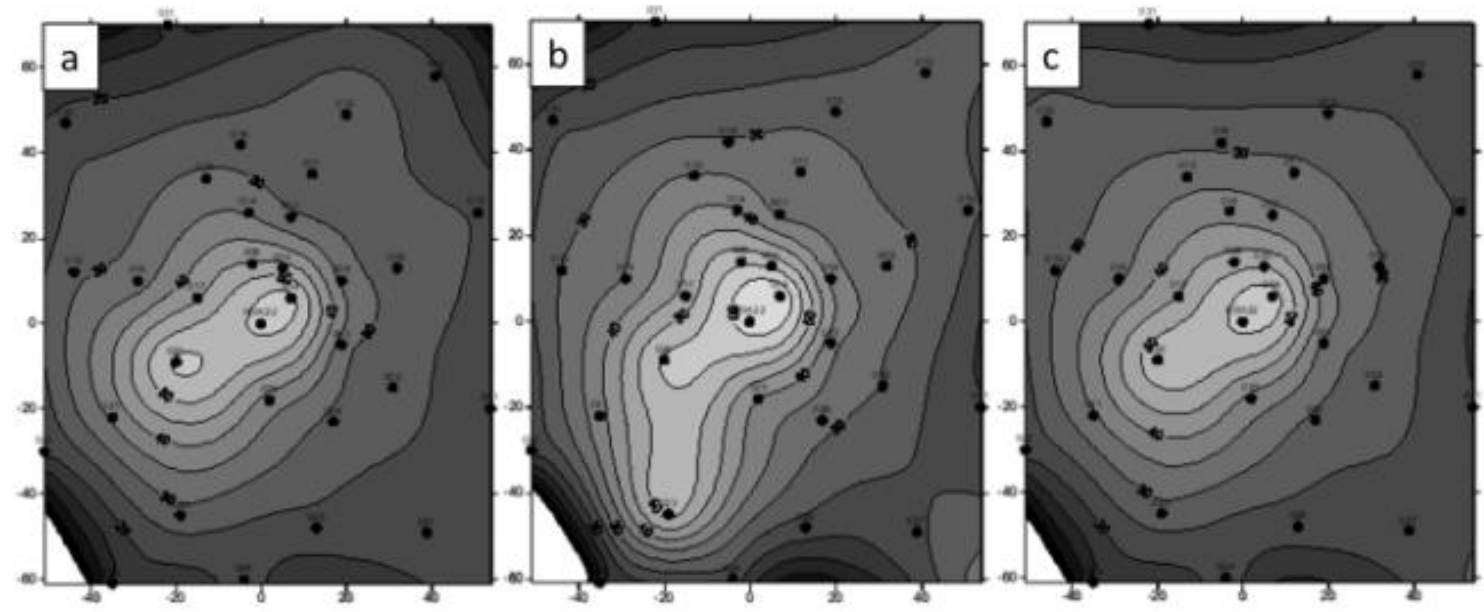

Figure 10. Resistivity map prior (a), during (b) and aftermath (c) of the steam injection.
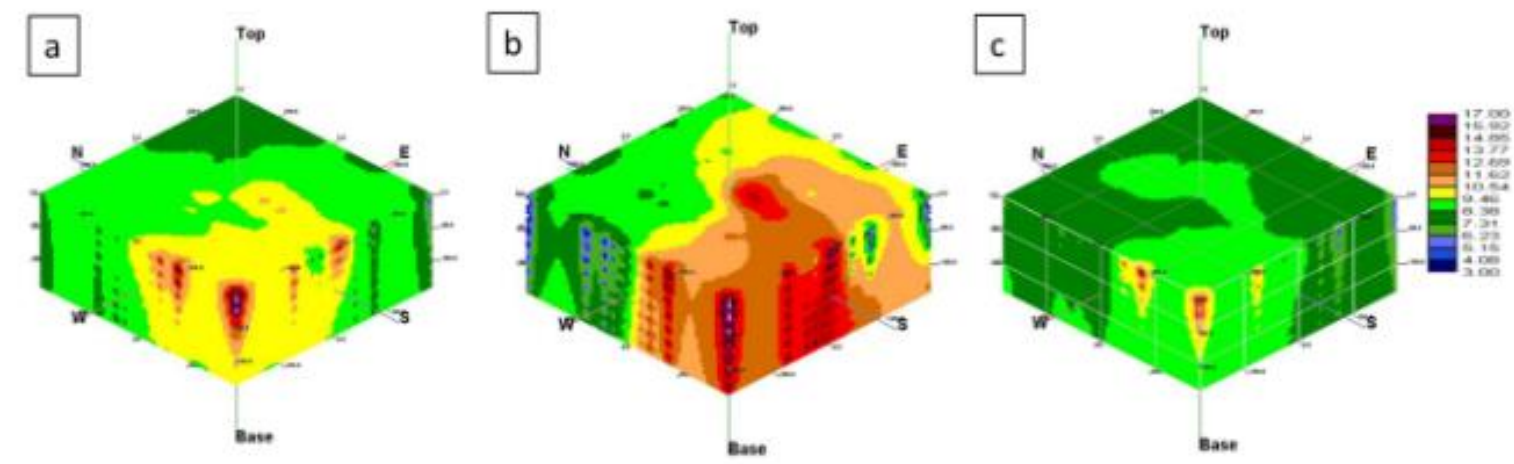

Figure 11. Three dimensional inversion result from acquired data during steam injection.

By the end of 2017, the latest version of LVG GLS has been completed. The device was able to measure from 120 electrodes simultaneously using a single current injection. Data acquisition could now be done to retrieve higher quality data in a shorter time frame. The latest version still requires to be proven through field testing.

\section{Conclusion}

1. Over the years, LEGG has been successful in developing a geoelectric measuring device which is specialized for Mise Ala Masse configuration.

2. Field testing has shown that the device could be well applied in the industry, geohazard mitigation and environmental geoscience.

3. While previous version of the LVG GLS has been proven to be well working in several field conditions. Latest version of the geoelectric measuring device still requires further testing. 
JСロNTES

\section{Acknowledgment}

The funding for development of the monitoring equipment mainly came from ITB Research and Community Services Institute. The author would also like to express his sincerest gratitude to the management of PT. BOB Siak Pusako for their permission to publish this paper. Special appreciation for the Faculty Earth Science and Technology for its continuous support to the Laboratory Exploration Geology and Geothermal by awarding Faculty Research Grant No. 0004/K01.03.2/PL2.1.5/I/2006 and P3MI research 2017. Finally, to all LVG/LEGG's staff, without their support the research and field works will not possible.

\section{References}

[1] Sumintadireja P., 2001, Application of Geostatistical and Neural Network Methods for Mise-ala-masse interpretation, Buletin Geologi ITB, vol.33, No.3, pp. 109-118

[2] Sumintadireja P., M. Fudiansyah and Diky Irawan, Fluid Flow Monitoring for Well Producing Through Casing Pipe Electrode, Jurnal Geoaplika, v.1 n.3, 2006

[3] Grandis, H and Irawan, D., 1D inversion model of Schlumberger VES data using Markov chain Monte Carlo (MCMC) method, Proceedings PIT HAGI, 37th HAGI Annual Convention \& Exhibition, Palembang, 2012.

[4] Grandis, H., Irawan, D. and Sumintadireja, P., Shallow to Moderate Resistivity Structure of a Geothermal Field, Proceedings 2nd ITB Geothermal Workshop 2013, Bandung, Indonesia, 2013.

[5] Mizunaga, H and Ushijima K, 1991, Three Dimensional Numerical Modeling for the Mise-a-lamasse Method, SEGJ, vol. 44, no. 4, pp 215-226

[6] Sumintadireja P., Sudarman S., Ushijima K., and Mizunaga H., 2000, Mise-a-la-masse and gravity data surveys at the Kamojang geothermal field, Proceeding World Geothermal Congress, Beppu-Morioka Japan, pp. 1777-1784. 